J. Amer. Soc. Hort. ScI. 115(2):202-207. 1990.

\title{
Ripening and Fruit Weight of Eight Strawberry Cultivars Respond to Row Cover Removal Date
}

\author{
Martin P.N. Gent \\ Department of Forestry and Horticulture, The Connecticut Agricultural Experiment Station, P. O. \\ Box 1106, New Haven, CT 06504 \\ Additional index words. Fragaria $\times$ ananassa fruit development, harvest date, yield
}

\begin{abstract}
Strawberry (Fragaria $\times$ ananassa Duchesn.) cultivars differ in response to removal date of row covers when they are used for winter protection and to accelerate fruit development and production. In 1986-87 and 198788, eight cultivars were overwintered under either spun-bonded polypropylene row cover or under straw. The straw was removed from control plots in late March. Row covers were removed on four dates beginning in late March and separated by about 2 -week intervals. The time of flowering, fruit set, and fruit ripening was advanced in direct relation to the time that row covers remained over plants in spring. The differences in time of fruit ripening were less than those of time of flowering, however. The mid-harvest date was advanced as much as 8 days for 'Earlidawn' and 'Midway', but only 4 days for 'Redchief' and 'Scott'. Weight per fruit and percentage of marketable fruit were reduced when plants remained under row cover until mid-May. This effect was most noticeable for 'Earlidawn', 'Guardian', and 'Redchief'. The fruit quality of 'Midway' and 'Jerseybelle' was not significantly affected by date of row cover removal. These cultivar-specific responses were probably not related to the stage of fruit development when row covers were removed, as both early and late-flowering cultivars were sensitive (and insensitive) to the date of row cover removal.
\end{abstract}

Strawberry, grown as a perennial in the northern United States, is usually overwintered under a straw mulch applied in November. Synthetic mulches and plant covers are alternatives to straw that may provide a way to extend the season of fruit production. In the upper Midwest, clear polyethylene both protected the plants from winter injury and resulted in earlier flowering (Hertz, 1979) and ripening (Scheel, 1986). In the Netherlands, perforated polyethylene tunnels increased yield and resulted in early

Received for publication 30 Jan. 1989. Mention of trade names does not constitute endorsement over similar materials with like properties. The cost of publishing this paper was defrayed in part by the payment of page charges. Under postal regulations, this paper therefore must be hereby marked advertisement solely to indicate this fact. ripening, but at the expense of fruit weight (Wijsmuller, 1986). The first harvest was advanced by covering plants until early May, but there was no additional earliness from later removal (Peerbooms and Veens, 1982). There appear to be limits to the acceleration of ripening by a prolonged period of row cover and some deleterious effects on fruit weight and quality.

In New Hampshire, spun-bonded polypropylene and polyester row covers increased yields over straw-mulched controls (Pollard and Cundari, 1988). The accumulation of growing degree days under row cover was greater than ambient in both fall and spring, resulting in accelerated plant development and earlier fruit ripening (J.E. Pollard, personal communication, 1988). Spun-bonded materials are porous and do not accumulate heat 
as much as polyethylene; therefore, it may be possible to cover strawberry with spun-bonded row covers until the fruit is nearly ripe. However, a longer duration of row cover may not benefit all strawberry cultivars. In New York, yield and fruit weight of two cultivars differed in their response to the date of removal of row cover (Pritts et al., 1989). Cultivar differences in pollination ability in the absence of insects (Connor and Martin, 1973) may be related to their response to the duration of cover. The number of blossoms pollinated while plants are covered, and isolated from insects, would increase with duration of cover.

In this study, cultivar-specific responses to duration of row cover in the spring were examined using spun-bonded floating row cover as over-winter protection.

\section{Materials and Methods}

Plant material and cultural conditions. In order of ripening, the June-bearing strawberries were: 'Earliglow', 'Earlidawn', 'Midway', 'Redchief', 'Guardian', 'Scott', and 'Jerseybelle'. The earliness of everbearing 'Tribute' was similar to 'Midway'. Yield trials were conducted at Lockwood Farm, Hamden, Corm., in 1987 and 1988. The soil, a fine sandy loam (mixed mesic Typic dystrochrept), had a $\mathrm{pH}$ of 6.0 and medium to high levels of all nutrients except $\mathrm{N}$. Black polyethylene mulch was applied over level beds $1.2 \times 20 \mathrm{~m}$ separated by $0.6-\mathrm{m}$ aisles, running east to west. On 7 and 8 May 1986, bare-rooted plants (obtained from Nourse Farms, South Deerfield, Mass.) were planted through the mulch in double rows with 0.6-m distance between plants. Plants were deblossomed through June. In July, two runners per plant were established as new plants. Thereafter, runners were removed to maintain plant density at five plants/m of row or 5.4 plants $/ \mathrm{m}^{2}$.

In mid-July of each year, $10 \mathrm{~N}-4.3 \mathrm{P}-8.3 \mathrm{~K}$ fertilizer was broadcast at a rate of $67 \mathrm{~kg} \mathrm{~N} / \mathrm{ha}$ and incorporated into the aisles. The mulched areas were weeded by hand. Aisles were sprayed with 1, 1'-dimethyl-4,4' -bipyridinium-dichloride (paraquat) twice each year. The plot was sprayed with 3-(3,5dichlorophenyl)-5-ethenyl-5-methyl-2,4-oxazo1idinedione (ronilan) and cis-N-trichloromethylthio-4-cyclohexene-1,2dicarboximide (captan) on 4 and 20 May to prevent fungus diseases on the fruit. After mid-April, when frost was predicted, the field was sprinkled from 2200 to 0600 HR to prevent damage to flowers. Overhead irrigation was used to prevent drought during fruit production.

Treatments. Spun-bonded polypropylene (Kimberly Farms floating row cover, Kimberly Clark Co., Roswell, Ga.) was applied in the fall. A double row of plants was covered with a $1.6-\mathrm{m}$-wide cover fastened by burying $0.1 \mathrm{~m}$ of each edge in the soil. The field was divided into four replicate plots arranged north to south. Each plot contained one row of each cultivar in random order. Row covers were applied to these plots on 22 Sept., 29 Sept., 10 Oct., or 17 Oct. in 1986. Within each plot, one 4-m section of row was left uncovered until 24 Nov. 1986, when it was covered with straw. Row covers were applied on 3 Sept., 6 Oct., 29 Oct., or 25 Nov. 1987 and an uncovered section in each row was covered with straw on 25 Nov. 1987.

The straw was removed from the field on 27 Mar. 1987 and 25 Mar. 1988. Each plot corresponding to a cover application date was divided into four subplots randomly arranged east to west containing a 4-m length of row of each cultivar. These subplots were uncovered on 27 Mar., 20 Apr., 1 May, or 14 May in 1987 and on 25 Mar., 14 Apr., 4 May, or 16 May in 1988.
Measurements. The number of open flowers and the number of fruit were counted on five adjacent plants per plot after each row cover removal date in 1987. In both years, fruit was harvested at 5-day intervals until production of June-bearing cultivars ceased. A 2-m length of row was harvested repeatedly from each subplot and weighed. A representative subsample of 25 fruit was graded into marketable and unmarketable fruit and weighed. Marketable fruit weighed $>6 \mathrm{~g}$ and had firm flesh and a symmetric shape. Accumulated yields and numbers of ripe fruit were determined for 20 subplots per cultivar. The midharvest date was determined for each subplot by linear interpolation between two actual harvest dates to estimate the time that exactly one-half the total yield was accumulated.

Statistical analysis. The experimental design was a factorial split plot with application date as the main plot, cultivar as the sub-plot, and removal date as the sub-sub-plot. The four application dates were treated as replicate plots in regression analysis to determine linear and quadratic responses to row cover removal date. The straw-covered control was not included in the regression.

\section{Results}

Flowering and fruit set. Row cover accelerated early vegetative growth and flowering. When row covers were removed on 20 Apr. 1987, the early cultivar Earliglow had about one open flower per plant, while plants overwintered under straw had none (Table 1). When row covers were removed on 1 May, plants had equal numbers of open flowers and immature fruit, while plants overwintered under straw had fewer open flowers and almost no fruit. Plants from which row covers were removed on 20 Apr. had fewer fruit than those under cover until 1 May. When row covers were removed on 14 May, the plants had four times more fruit set than plants overwintered under straw. Plants covered until 14 May also had more fruit set than plants covered until 20 Apr. 1987. Thus, the acceleration of flower development and fruit set by row cover continued throughout the spring until the row cover was removed. Fruit set was not prevented by row cover, since plants covered until 14 May had already set as many fruit as the total number picked from 'Earliglow' plots overwintered under straw in 1987 (data not shown).

Flower and fruit development of 'Jerseybelle' were 8 days behind those of 'Earliglow'; plants were not in full bloom until 14 May. 'Jerseybelle' covered until 14 May had set more fruit than plants with row cover removed earlier. However, the number of fruit set was only about one-half the total number picked from 'Jerseybelle' in 1987. Although the row cover removal dates corresponded to different development stages for early and late cultivars, the acceleration of development by row cover was similar for all cultivars. On 2 May, plant development under row cover was similar to that in mid-May for plants overwintered under straw.

Fruit production. Averaged over all cultivars and row cover treatments, row covers increased total and marketable yields and decreased midharvest date, marketable percentage, and fruit weight with respect to straw mulch (Gent, 1989). The significance levels for these effects are given in Table 2. Using row cover instead of straw as winter protection increased total yield from 13.1 to 16.3 t-ha- $^{1}$ in 1987 . Row cover increased yields less in 1988, from 16.6 to 17.1 t-ha- $^{-}$. Row cover increased marketable yields less than total yields (data not shown). Yield increases due to row cover were reported for 'Earliglow' in New Hampshire (Pollard and Cundari, 1988) and New York (Pritts 
Table 1. Effect of row cover removal date on flowering and fruit set of 'Earliglow' and 'Jerseybelle' strawberry in 1987.

\begin{tabular}{|c|c|c|c|c|c|c|}
\hline \multirow{3}{*}{$\begin{array}{l}\text { Removal } \\
\text { date }\end{array}$} & \multicolumn{6}{|c|}{ Measurement date } \\
\hline & \multicolumn{2}{|c|}{20 Apr. } & \multicolumn{2}{|c|}{2 May } & \multicolumn{2}{|c|}{14 May } \\
\hline & Flower & Fruit & Flower & Fruit & Flower & Fruit \\
\hline & \multicolumn{6}{|c|}{ Number/plant } \\
\hline Earliglow & & & & & & \\
\hline Straw control & 0.0 & 0.0 & $3.5 b^{z}$ & $0.5 \mathrm{~d}$ & $11.7 \mathrm{~b}$ & $11.4 \mathrm{c}$ \\
\hline 27 Mar. & 0.5 & 0.0 & $5.8 \mathrm{ab}$ & $3.1 \mathrm{c}$ & $16.7 \mathrm{a}$ & $26.9 \mathrm{~b}$ \\
\hline 20 Apr. & 0.8 & 0.0 & $7.8 \mathrm{a}$ & $6.4 \mathrm{~b}$ & $8.7 \mathrm{~b}$ & $23.6 \mathrm{~b}$ \\
\hline 1 May & --- & $\cdots$ & $7.9 \mathrm{a}$ & $9.4 \mathrm{a}$ & $8.0 \mathrm{~b}$ & $36.5 \mathrm{a}$ \\
\hline 14 May & $\cdots$ & -- & --- & -- & $7.5 \mathrm{~b}$ & $41.1 \mathrm{a}$ \\
\hline \multicolumn{7}{|l|}{ Jerseybelle } \\
\hline Straw control & 0.0 & 0.0 & $0.0 \mathrm{~b}$ & $0.0 \mathrm{~b}$ & $4.5 \mathrm{~b}$ & $0.6 \mathrm{~d}$ \\
\hline 27 Mar. & 0.0 & 0.0 & $0.7 \mathrm{~b}$ & $0.1 \mathrm{~b}$ & $7.9 \mathrm{ab}$ & $2.7 \mathrm{~cd}$ \\
\hline $20 \mathrm{Apr}$. & 0.0 & 0.0 & $2.3 \mathrm{a}$ & $0.3 \mathrm{~b}$ & $7.8 \mathrm{ab}$ & $6.7 \mathrm{c}$ \\
\hline 1 May & -.. & --- & $3.3 \mathrm{a}$ & $1.0 \mathrm{a}$ & $8.9 \mathrm{a}$ & $11.5 \mathrm{~b}$ \\
\hline 14 May & -- & --- & $--\cdot$ & -- & $9.5 \mathrm{a}$ & $16.9 \mathrm{a}$ \\
\hline
\end{tabular}

${ }^{2}$ Mean separation by Duncan's multiple range test in columns within cultivar significant at $P=0.05$.

Table 2. Significance levels for main effects and interactions of year, cultivar, and winter mulch, and application and removal dates of row covers on fruit production of eight strawberry cultivars.

\begin{tabular}{lccccc}
\hline \hline & \multicolumn{5}{c}{ Variable } \\
\cline { 2 - 7 } Factor & $\begin{array}{c}\text { Total } \\
\text { yield }\end{array}$ & $\begin{array}{c}\text { Marketable } \\
\text { yield }\end{array}$ & $\begin{array}{c}\text { Midharvest } \\
\text { date }\end{array}$ & $\begin{array}{c}\text { Marketable } \\
\text { percentage }\end{array}$ & $\begin{array}{c}\text { Fruit } \\
\text { weight }\end{array}$ \\
\hline Row cover vs. straw & & \multicolumn{4}{c}{ Significance level } \\
Year (Y) & 0.001 & 0.003 & 0.05 & 0.001 & $\mathrm{NS}$ \\
Cultivar (C) & 0.001 & 0.05 & 0.001 & 0.001 & 0.001 \\
Mulch type (M) & 0.001 & 0.05 & 0.001 & 0.001 & 0.001 \\
$\mathrm{Y} \times \mathrm{C}$ & 0.001 & 0.01 & 0.006 & $\mathrm{NS}$ & 0.03 \\
$\mathrm{Y} \times \mathrm{M}$ & 0.005 & $\mathrm{NS}$ & $\mathrm{NS}$ & 0.10 & $\mathrm{NS}$ \\
$\mathrm{C} \times \mathrm{M}$ & $\mathrm{NS}$ & $\mathrm{NS}$ & $\mathrm{NS}$ & $\mathrm{NS}$ & $\mathrm{NS}$ \\
$\mathrm{Y} \times \mathrm{C} \times \mathrm{M}$ & $\mathrm{NS}$ & $\mathrm{NS}$ & $\mathrm{NS}$ & $\mathrm{NS}$ & $\mathrm{NS}$ \\
Within row cover treatments & & & & \\
Application (A) & 0.001 & 0.001 & $\mathrm{NS}$ & $\mathrm{NS}$ & $\mathrm{NS}$ \\
$\mathrm{Removal}(\mathrm{R})$ & 0.001 & 0.001 & 0.001 & 0.001 & 0.001 \\
$\mathrm{C} \times \mathrm{A}$ & $\mathrm{NS}$ & $\mathrm{NS}$ & $\mathrm{NS}$ & $\mathrm{NS}$ & 0.01 \\
$\mathrm{C} \times \mathrm{R}$ & $\mathrm{NS}$ & $\mathrm{NS}$ & $\mathrm{NS}$ & 0.01 & 0.02 \\
$\mathrm{~A} \times \mathrm{R}$ & 0.04 & 0.05 & 0.001 & $\mathrm{NS}$ & $\mathrm{NS}$ \\
Pooled SE & $1.9 \mathrm{t} \cdot \mathrm{ha}^{\mathrm{t}}$ & $1.7 \mathrm{t} \cdot \mathrm{ha}^{-1}$ & 0.9 days & 0.03 & $0.8 \mathrm{~g}$ \\
\hline
\end{tabular}

${ }^{2}$ Standard error of mean within cultivar and row cover removal date as reported in Tables 3-5.

${ }^{\text {Ns }}$ Not significant.

et al., 1989). Within row cover treatments, removal date had a significant effect on total yield only when plants remained covered until 16 May 1988. These plants yielded $2.2 \mathrm{t} \cdot \mathrm{ha}^{-1}$ less than plants with row cover removed earlier. Similar results were noted for 'Earliglow' in New York (Pritts et al., 1989). Within row cover treatments, total and marketable yields seemed to increase with earlier fall application date. However, the same yield increases were seen among the straw-covered controls in each plot, suggesting that this was an effect of location rather than of treatment.

Early cultivars produced the first ripe fruit on 21 May 1987 and 24 May 1988. Compared to plants overwintered under straw, the mid-harvest date for plants overwintered under row cover that was removed in late March was 1.2 and 2.8 days earlier, averaged over all cultivars in 1987 and 1988, respectively. Ripening was advanced more when plants remained covered until early May (Table 3). The mid-harvest dates of 'Midway' and 'Earliglow' were advanced the most compared to straw-covered controls, $\approx 8$ days. The mid-harvest dates of 'Redchief' and 'Tribute' were advanced the least, $\approx 4$ days. In general, the midharvest date of all cultivars was advanced more the longer the duration of row cover. For each cultivar, the mid-harvest dates were regressed against the date of row cover removal. An inverse relation between the date of row cover removal and midharvest date was significant for all cultivars in 1987. In 1988, this relationship was not significant for 'Earlidawn' and 'Redchief'. Averaged over all cultivars in 1987, plants covered until mid-May ripened 1 day earlier than those covered until early 
Table 3. Effect of row cover removal date on mid-harvest date of eight strawberry cultivars in 1987 and 1988.

\begin{tabular}{|c|c|c|c|c|c|c|c|c|}
\hline \multirow{2}{*}{$\begin{array}{l}\text { Removal } \\
\text { date }\end{array}$} & \multicolumn{8}{|c|}{ Cultivar } \\
\hline & E'dawn & E'glow & Guardian & J'Belle & Midway & Redchief & Scott & Tribute \\
\hline \multicolumn{4}{|l|}{1987} & \multicolumn{3}{|c|}{ Mid-harvest date } & & \\
\hline Straw & 7 June & 4 June & 8 June & 13 June & 7 June & 8 June & 9 June & 7 June \\
\hline 27 Mar. & 3 & 3 & 7 & 11 & 6 & 7 & 9 & 7 \\
\hline $20 \mathrm{Apr}$. & 2 & 31 May & 6 & 10 & 3 & 5 & 7 & 6 \\
\hline 1 May & 1 & 30 & 5 & 8 & 1 & 4 & 5 & 4 \\
\hline 14 May & 29 May & 30 & 4 & 8 & 30 May & 4 & 5 & 3 \\
\hline Linear & $*$ & $* *$ & $*$ & $* *$ & $* *$ & $* *$ & $* *$ & $* *$ \\
\hline Quadratic & NS & NS & NS & NS & NS & NS & NS & NS \\
\hline \multicolumn{9}{|c|}{1988 (all dates in June) } \\
\hline Straw & 13 & 11 & 15 & 20 & 12 & 14 & 17 & 12 \\
\hline 25 Mar. & 8 & 9 & 12 & 19 & 9 & 12 & 16 & 9 \\
\hline 14 Apr. & 9 & 8 & 11 & 18 & 6 & 11 & 14 & 9 \\
\hline 4 May & 4 & 6 & 9 & 15 & 4 & 8 & 12 & 8 \\
\hline 16 May & 5 & 4 & 9 & 15 & 3 & 10 & 13 & 7 \\
\hline Linear & NS & $* *$ & $*$ & ** & $* *$ & NS & * & * \\
\hline Quadratic & NS & NS & NS & NS & NS & NS & NS & NS \\
\hline
\end{tabular}

May. In 1988, covering until mid-May did not advance ripening compared to covering until early May.

The percentage of marketable fruit was sensitive to date of row cover removal. Averaged over all cultivars, there was little difference between plants overwintered under straw and plants overwintered under row cover that was removed by early May (Table 4). However, the percentage of marketable fruit was substantially less for plants under row cover until mid-May, especially in 1988. Regression of percentage of marketable fruit vs. date of row cover removal resulted in a quadratic response. In addition, the percentage of marketable fruit of 'Guardian' and 'Redchief' showed a linear decline with date of row cover removal in both years. The percentage of marketable fruit of these cultivars was most sensitive to the date of removal of row cover. The fruit quality of 'Midway' and 'Jerseybelle' was affected least.

Fruit weight was greater for plants overwintered under straw than for those overwintered under row cover (Table 5). Except for 'Midway' and 'Tribute', fruit weight, like marketable yield, decreased on plants covered until mid-May 1988. Fruit weight of 'Earlidawn', 'Guardian', and 'Redchief' decreased > 30\%. In 1988, fruit weights of these sensitive cultivars declined linearly with date of row cover removal. In 1987, fruit weight of 'Guardian', 'Redchief', and 'Scott' were sensitive to row cover removal date and the weight per fruit decreased linearly as the row cover period was extended.

Table 4. Effect of row cover removal date on percentage of marketable fruit of eight strawberry cultivars in 1987 and 1988.

\begin{tabular}{|c|c|c|c|c|c|c|c|c|}
\hline \multirow{2}{*}{$\begin{array}{c}\text { Removal } \\
\text { date }\end{array}$} & \multicolumn{8}{|c|}{ Cultivar } \\
\hline & E'dawn & E'glow & Guardian & J'Belle & Midway & Redchief & Scott & Tribute \\
\hline \multicolumn{9}{|l|}{1987} \\
\hline Straw & 89 & 91 & 90 & 84 & 83 & 86 & 84 & 75 \\
\hline 27 Mar. & 83 & 86 & 87 & 82 & 81 & 85 & 79 & 69 \\
\hline 20 Apr. & 74 & 82 & 84 & 85 & 84 & 81 & 87 & 82 \\
\hline 1 May & 84 & 83 & 82 & 83 & 81 & 84 & 83 & 72 \\
\hline 14 May & 80 & 73 & 74 & 84 & 81 & 76 & 74 & 70 \\
\hline Linear & NS & $*$ & $*$ & NS & NS & $* *$ & NS & NS \\
\hline Quadratic & NS & NS & NS & NS & NS & $*$ & $*$ & $*$ \\
\hline \multicolumn{9}{|l|}{1988} \\
\hline Straw & 74 & 92 & 91 & 92 & 86 & 86 & 87 & 83 \\
\hline 25 Mar. & 86 & 90 & 88 & 89 & 85 & 85 & 80 & 82 \\
\hline 14 Apr. & 82 & 90 & 87 & 92 & 85 & 85 & 86 & 80 \\
\hline 4 May & 80 & 90 & 88 & 93 & 82 & 83 & 86 & 77 \\
\hline 16 May & 68 & 82 & 72 & 85 & 82 & 69 & 78 & 73 \\
\hline Linear & $* *$ & $*$ & $* *$ & NS & NS & $* *$ & NS & $*$ \\
\hline Quadratic & NS & $* *$ & $* *$ & $*$ & NS & $* *$ & $* *$ & NS \\
\hline
\end{tabular}


Table 5. Effect of row cover removal date on weight per fruit at mid-harvest of eight strawberry cultivars in 1987 and 1988.

\begin{tabular}{lcccccccc}
\hline \hline \multirow{2}{*}{$\begin{array}{c}\text { Removal } \\
\text { date }\end{array}$} & \multicolumn{7}{c}{ Cultivar } \\
\cline { 2 - 9 } & E'dawn & E'glow & Guardian & J'Belle & Midway & Redchief & Scott & Tribute \\
\hline 1987 & \multicolumn{7}{c}{$g$ /fruit } \\
Straw & 11.9 & 12.0 & 15.3 & 14.3 & 11.6 & 11.4 & 13.3 & 9.3 \\
27 Mar. & 9.8 & 12.1 & 15.5 & 14.5 & 10.3 & 11.3 & 12.8 & 8.3 \\
20 Apr. & 10.6 & 11.4 & 13.7 & 14.7 & 9.7 & 11.0 & 11.3 & 9.0 \\
1 May & 9.8 & 10.7 & 11.1 & 15.5 & 9.9 & 10.5 & 11.2 & 8.2 \\
14 May & 7.5 & 10.6 & 11.4 & 12.3 & 10.4 & 9.3 & 10.4 & 8.0 \\
Linear & NS & NS & $* *$ & NS & NS & $*$ & $*$ & NS \\
Quadratic & NS & NS & NS & NS & NS & NS & NS & NS \\
1988 & & & & & & & & \\
Straw & 9.8 & 14.6 & 14.0 & 15.5 & 11.5 & 11.8 & 10.5 & 9.6 \\
25 Mar. & 10.2 & 12.0 & 14.9 & 13.9 & 10.6 & 11.4 & 9.3 & 8.1 \\
14 Apr. & 10.5 & 11.3 & 14.6 & 15.4 & 9.5 & 9.9 & 10.4 & 8.1 \\
4 May & 7.7 & 11.7 & 13.9 & 15.2 & 9.7 & 9.2 & 10.1 & 7.5 \\
16 May & 7.2 & 9.8 & 9.7 & 10.9 & 9.3 & 7.3 & 7.7 & 8.2 \\
Linear & $* *$ & $*$ & $* *$ & NS & NS & $* *$ & NS & NS \\
Quadratic & NS & NS & $*$ & $*$ & NS & NS & $* *$ & NS \\
\hline
\end{tabular}

NS, ${ }^{*}, * *$ Not significant or significant at $P=0.05$ and 0.01 , respectively, for linear or quadratic regression vs. row cover removal date, not including straw-covered control.

\section{Discussion}

In general, the weight of the first fruit picked from each plot of a given cultivar was similar whether overwintered under floating row cover or under straw (Gent, 1989). The weight per fruit from later harvests was smaller for plants under row cover. In this case, the lower weight per fruit likely was due to an increased contribution of secondary and tertiary fruit to the total yield. When the duration of row cover was extended to midMay, the weight of the first fruit picked was decreased dramatically in some cultivars. The weight of the primary fruit was probably reduced in this case. For instance, the first fruit picked from 'Guardian' overwintered under straw or under row covers removed in late March weighed 18 and $22 \mathrm{~g}$ in 1987 and 1988, respectively. When row covers were removed in mid-May, the respective weights of the first fruit picked were 13 and $15 \mathrm{~g}$.

Mid-harvest dates of all cultivars in this trial were earlier the later that row covers were removed in the spring. However, row covers reduced the percentage of marketable fruit and fruit weight in 'Earlidawn', 'Guardian', and 'Redchief'. Marketable percentage and fruit weight were relatively unaffected by the date of row cover removal in 'Jerseybelle', 'Midway', and 'Tribute'. The sensitivity of 'Earliglow' to date of row cover removal was intermediate. In New York, the fruit weight of 'Earliglow' was more sensitive to row cover removal date than was that of 'Allstar' (Pritts et al., 1989). The deleterious effects of row cover were probably not due to cover during a specific stage of plant development, as cultivar sensitivity to row cover was not related to earliness. For instance, the fruit weight of early and late cultivars 'Midway' and 'Jerseybelle' was not sensitive to row cover removal date, despite differences in timing of fruit development with respect to dates of row cover removal. Conversely, the early and late cultivars Earlidawn and Guardian were both sensitive to date of row cover removal.

Row covers prevented insect pollination of flowers. Windinduced pollination was sufficient to allow good fruit set. However, achene development and fruit weight may be reduced compared to insect-pollinated flowers (Connor and Martin, 1973). Cultivars differed in this characteristic; 'Guardian' and 'Earlidawn' had a low ranking in achene development in the absence of insects, while 'Midway' had a high ranking (Connor and Martin, 1973). In the present study, marketable yield and fruit weight of 'Earlidawn' and 'Guardian' were reduced by prolonged row cover, while 'Midway' was not affected. Those cultivars that produced smaller fruit when row covers remained past full bloom probably had a greater requirement for insect pollination.

During early May, maximum ambient temperatures were $>25 \mathrm{C}$ and temperatures under row cover were even warmer. Midharvest dates for plants covered until mid-May in 1988 were not advanced with respect to plants covered only until early May. Temperatures under row cover likely exceeded the optimum for strawberry flower development and fruit set. In a study of the interaction of photoperiod and temperature on inflorescence development in strawberry, Durner et al. (1984) reported that temperatures $>25 \mathrm{C}$ reduced the number of inflorescences in all cultivars examined. Supra-optimal temperatures under row cover during May also may have been a factor in reduced marketable yields and fruit weight of nearly all the cultivars in 1988.

\section{Literature Cited}

Connor, L.J. and E.C. Martin. 1973. Components of pollination of commercial strawberries in Michigan. HortScience 8:304-306.

Durner, E. F., J.A. Barden, D.G. Himelrick, and E.B. Poling. 1984. Photoperiod and temperature effects on flower and runner development in day-neutral, Junebearing and everbearing strawberries. J. Amer. Soc. Hort. Sci. 109:396-400.

Gent, M.P.N. 1989. Effect of floating row cover as a winter mulch on eight strawberry cultivars. Corm. Agr. Expt. Sta. Bul. 866.

Hertz, L.B. 1979. The effectiveness of Sudangrass straw and polyethylene mulches on the growth and yield of 'Trumpeter' strawberry, HortScience 14:236-238.

Peerbooms, M. and T. Veens. 1982. Tijdstip verijderen geperforeede folie bij aardbeiern zeer belangrijk. [The time of removing perforated film from strawberries is very important] [in Dutch, English abstract]. Fruitteelt 72:558-559.

Pollard, J.E. and C.M. Cundari. 1988. Over-wintering strawberry plants under row cover increases fruit production. HortScience 23:232233.

Pritts, M. P., K.A. Worden, and M. Eames-Sheavly. 1989. Rowcover 
material and time of application and removal affect ripening and yield of strawberries. J. Amer. Soc. Hort. Sci. 114:531-536.

Scheel, D.C. 1986. The effect of clear polyethylene winter mulch on the growth and yield of strawberries. Adv. Strawberry Prod. 1:2930 .
Wijsmuller, J. 1986. Oostspeirding bij aardbeiern. [Spreading the harvest of strawberries] [in Dutch, English abstract]. Fruitteelt 72:316317. 